\title{
EVALUASI PELAKSANAAN PEMBELAJARAN INSTALASI PENERANGAN LISTRIK KOMPETENSI KEAHLIAN TIPTL SMK NEGERI 3 SINGARAJA
}

\author{
K. A. S. wibawa ${ }^{1}$, N. Santiyadnya ${ }^{2}$, G. Indrawan ${ }^{3}$ \\ 1.2Prodi Pendidikan Teknik Elektro, Universitas Pendidikan Ganesha, Singaraja \\ ${ }^{3}$ Prodi Teknik Elektronika, Universitas Pendidikan Ganesha, Singaraja \\ e-mail: joniartawan19@yahoo.co.id, santiyadnya@undiksha.ac.id, gindrawan@undiksha.ac.id
}

\begin{abstract}
Abstrak
Penelitian ini bertujuan mengevaluasi dan mendeskripsikan pelaksanaan pembelajaran pada mata pelajaran instalasi penerangan listrik kompetensi keahlian (TIPTL) SMK Negeri 3 Singaraja. Bentuk Penelitian ini adalah penelitian kualitatif deskriptif. Sumber data penelitian ini diperoleh secara purposive sampling. Teknik pengumpulan data dilaksanakan dengan observasi partisipasi pasif, wawancara terstruktur, dan kajian studi dokumen. Sumber data utama diperoleh dua orang guru kelas XI dan data penunjang diperoleh dari enam orang siswa kelas XI TIPTL. Ada 3 proses analisis data meliputi analisis sebelum, selama, dan setelah di lapangan. Aktivitas analisis data selama di lapangan terdiri atas reduksi data, penyajian data, penarikan kesimpulan/verifikasi. Pengujian keabsahan data dilaksanakan melalui validitas internal, validitas eksternal, uji dependability, dan uji conformability. Berdasarkan hasil penelitian, didapatkan antara lain. 1) komponen Rancangan Program Pembelajaran (RPP) yang disusun guru sudah sesuai dengan arahan Permendikbud No. 22 Tahun 2016, namun masih terdapat beberapa kekurangan. 2) pelaksanaan pembelajaran yang dilakukan guru meliputi pendahuluan, kegiatan inti, dan penutup. 3) evaluasi pembelajaran yang dilakukan guru sudah mengacu pada Permendikbud No. 23 Tahun 2016 yang meliputi aspek sikap, pengetahuan dan keterampilan, namun belum terealisasi secara maksimal karena terdapat item-item pada setiap aspek belum terlaksana semua.
\end{abstract}

Kata kunci: Evaluasi, Pembelajaran, IPL

\begin{abstract}
This study aimed to evaluate and describe the learning implementation in electrical lighting installation subject competency skills (TIPTL) at SMK Negeri 3 Singaraja. This study was a descriptive qualitative research. The source of data was obtained by purposive sampling. The data collection techniques were implemented by using the observation of passive participation, structured interviews, and a review of document study. The sources of the main data were obtained from two teachers in XI class and the supporting data were obtained from six students of XI TIPTL class. There were three stages of the data analysis process namely: analysis before, during, and after in the field. There were some activities conducted in the field during the data analysis process i.e., data reduction, data display, drawing conclusions / verification. The data validity test was carried out through internal validity, external validity, dependability test, and conformability test. Based on the results of the study, it was obtained that 1) The Lesson Plan (RPP) components have already arranged by the teachers based on Permendikbud No. 22, 2016, but there were still drawbacks. 2) There were pre-activity, whilst-activity and post-activity in the learning process that was conducted by the teachers. 3) The learning evaluation that conducted by the teachers have already refer to Permendikbud No. 23, 2016 which covers the aspects of attitude, knowledge and skills but the realization was not maximal yet because there were some items on each aspect that were not implemented yet.
\end{abstract}

Keywords: Evaluation, Learning, IPL

\section{Pendahuluan}

Salah satu sektor yang paling penting dalam pembangunan nasional di suatu Negara dilihat dari adanya sektor pendidikan. Hal ini dikarenakan dengan melalui sektor pendidikan dapat dibentuk manusia yang berkualitas, seperti yang disebutkan dalam Undang-Undang No. 20 Tahun 2003 tentang Sistem Pendidikan Nasional Bab II Pasal 3 bahwa Pendidikan 
nasional berfungsi mengembangkan kemampuan dan membentuk watak seperti peradaban bangsa yang bermartabat dalam rangka mencerdaskan kehidupan bangsa, bertujuan untuk berkembangnya potensi peserta didik agar menjadi manusia yang beriman dan bertaqwa kepada Tuhan Yang Maha Esa, berakhlak mulia, sehat, berilmu, cakap, kreatif, mandiri, menjadi warga negara yang demokratis serta bertanggung jawab.

Perkembangan jaman saat ini menuntut adanya sumber daya manusia yang berkualitas sehingga mampu bersaing dengan negara lain yang telah maju. Pendidikan mempunyai peranan yang sangat penting dalam menciptakan sumber daya manusia yang berkualitas. Pendidikan yang berkualitas akan berpengaruh pada kemajuan diberbagai bidang. Di samping mengusahakan pendidikan yang berkualitas, pemerintah perlu melakukan perataan pendidikan dasar bagi setiap Warga Negara, agar mampu berperan serta dalam memajukan kehidupan bangsa.

Jalur pendidikan sekolah di Indonesia dilaksanakan secara berjenjang yang terdiri dari jenjang pendidikan dasar, pendidikan menengah dan pendidikan tinggi. Pendidikan menengah terdiri dari dua kelompok, yaitu Sekolah Menengah Umum (SMU) dan Sekolah Menengah Kejuruan (SMK). Sekolah Menengah Kejuruan (SMK) merupakan lembaga pendidikan yang bertujuan untuk menyiapkan peserta didik menjadi tenaga kerja yang terampil, kreatif, produktif serta dapat mengisi pekerjaan sesuai kompetensi keahlian yang telah ditekuni. Pendidikan menengah kejuruan atau biasa disebut Sekolah Menengah Kejuruan (SMK) merupakan pendidikan pada jenjang pendidikan menengah yang mengutamakan pengembangan kemampuan siswanya untuk dapat bekerja dalam bidang tertentu, kemampuan beradaptasi di lingkungan kerja, melihat peluang kerja dan pengembangan diri dikemudian hari. Sekolah Menengah Kejuruan (SMK) merupakan salah satu lembaga pendidikan kejuruan yang memiliki tugas mempersiapkan peserta didiknya dengan membekali pengetahuan dan keterampilan untuk dapat bekerja sesuai dengan kompetensi dan program keahlian, memiliki daya adaptasi dan daya saing yang tinggi untuk memiliki lapangan kerja. Harapan masyarakat terhadap pendidikan kejuruan adalah mutu lulusan Sekolah Menengah Kejuruan (SMK) yang mempunyai kompetensi sesuai bidang keahliannya sehingga dapat diterima di Dunia Usaha/Dunia Industri (DU/DI) atau mampu mengembangkan melalui wirausaha.

Kemampuan calon tenaga kerja tidak akan lepas dari upaya yang dilakukan Sekolah Menengah Kejuruan (SMK). Salah satu usaha untuk meningkatkan lulusan yang berkualitas yaitu dengan menyempurnakan proses belajar mengajar. Peranan proses belajar mengajar di sekolah sangat penting karena disinilah semua ilmu akan diajarkan kepada peserta didik, untuk itu proses pembelajaran harus dilaksanakan dengan sebaik-baiknya, baik dari segi perencanaan, pelaksanaan, dan penilaian agar tujuan pembelajaran dapat dicapai sesuai dengan yang diharapkan. Ruang lingkup proses mulai dari perencanaan, pelaksanaan hingga penilaian merupakan hal yang paling menentukan dalam pembelajaran. Hal ini dikarenakan dalam proses pembelajaran berbagai mata pelajaran yang berhubungan dengan industri diajarkan, mulai dari ketepatan waktu pemberian pelajaran ataupun materi, kesesuaian silabus dengan RPP, kesesuaian waktu pemberian pelajaran teori maupun pelajaran praktik di sekolah dan di lapangan, dan ketersediaan fasilitas penunjang kegiatan pembelajaran peserta didik seperti halnya buku cetak ataupun berupa modul pembelajaran dengan mata pelajaran tertentu.

Ruang lingkup pembelajaran di Sekolah Menengah Kejuruan (SMK) meliputi tiga yaitu normatif, adaptif, dan produktif. Dalam ruang lingkup produktif dimana menjadi hal yang sangat penting bagi peserta didik di Sekolah Menengah Kejuruan (SMK) untuk mengembangkan potensi melalui pembelajaran produktif. Dalam pembelajaran produktif mencakup 3 ruang lingkup penilaian yang dimana penilaian hasil belajar peserta didik mencakup kompetensi sikap, pengetahuan, dan keterampilan yang dilakukan secara berimbang sehingga dapat digunakan untuk menentukan posisi relatif setiap peserta didik terhadap standar yang telah ditetapkan. Cakupan penilaian merujuk pada ruang lingkup materi, kompetensi mata pelajaran/kompetensi muatan/kompetensi program, dan proses (Kunandar, 2015: 52). Ketiga ruang lingkup tersebut sangatlah berperan penting bagi 
pengembangan diri peserta didik. Adapun juga penentu keberhasilan pembelajaran dalam ruang lingkup produktif di Sekolah Menengah Kejuruan (SMK) adalah tenaga pendidik. Tugas seorang tenaga pendidik di sekolah adalah mengembangkan potensi peserta didik, dengan menentukan strategi dan metode pembelajaran, serta pendekatan dan model penilaian yang digunakan.

Berdasarkan pengamatan yang peneliti lakukan di SMK Negeri 3 Singaraja khsususnya pada Kompetensi Keahlian Teknik Instalasi Pemanfaatan Tenaga Listrik (TIPTL), peneliti menemukan kesenjangan terhadap proses pembelajaran di Kompetensi Keahlian Teknik Instalasi Pemanfaatan Tenaga Listrik (TIPTL) di SMK Negeri 3 Singaraja khususnya pada mata pelajaran Instalasi Penerangan Listrik (IPL). Kesenjangan yang dimaksud yaitu dimana kurang sesuainya proses pembelajaran dari segi perencanaan terhadap pelaksanaan di dalam kelas, perencanaan yang dimaksud yaitu berupa Silabus serta Rencana Pelaksanaan Pembelajaran (RPP).

Menurut H.E Mulyasa (2010: 134-135) kurikulum difotokopi dari sekolah atau lembaga lain dengan cara copy file, kurikulum ini sering juga disebut kurikulum "Copy Paste", karena dalam hal ini biasanya guru hanya membuka file terus menekan tombol copy dan tombol paste, maka jadilah sebuah kurikulum dengan hanya mengganti jilidnya saja. Ada juga yang menyebutnya kurikulum "Rename", karena guru hanya menekan (klik) tombol rename kemudian mengganti namanya dengan nama sekolahnya, maka jadi pula sebuah kurikulum. Proses pengembangan kurikulum seperti itu merupakan hal yang dianggap sah oleh pemerintah. Ini dilakukan terutama untuk mempercepat sosialisasi dan implementasi kurikulum. Akan tetapi, proses pengembanga kurikulum yang demikian harus diadaptasikan, dimodifikasi, ditambah, dan dikurangi, sesuai dengan kondisi sekolah masing-masing, tidak hanya copy paste atau rename dan mengganti jilidnya tanpa dianalisis dahulu isinya. Sehingga mengakibatkan kurang sesuainya antara perencanaan terhadap pelaksanaan pembelajaran dengan kata lain pembelajaran menjadi kurang efektif. Tidak sedikit guru yang melakukan hal demikian, dengan alasan karena dikejar waktu.

Berdasarkan dengan permasalahan yang telah dibahas pada latar belakang diatas, maka tujuan penelitian ini adalah untuk mengetahui serta mendeskripsikan proses pembelajaran dari segi perencanaan, pelaksanaan, dan penilaian pada mata pelajaran Instalasi Penerangan Listrik (IPL) serta mengetahui faktor-faktor yang mempengaruhi kurang sesuainya antara tahap perencanaan terhadap pelaksanaan pembelajaran di dalam kelas.

Menurut Tyler (dalam Tayibnapis, 2008) evaluasi ialah proses yang menentukan sampai sejauh mana tujuan pendidikan dapat dicapai. Menurut Sukardi (2014: 5) evaluasi program merupakan rangkaian kegiatan yang dilakukan dengan sengaja dan secara cermat untuk mengetahui tingkat keterlaksanaan atau keberhasilan suatu program dengan cara mengetahui efektivitas masing-masing komponennya, baik terhadap program yang sedang berjalan maupun program yang telah berlalu.

Hadari Nawawi (dalam Abdul Majid, 2009: 16) mengatakan bahwa perencanaan berarti menyusun langkah-langkah penyelesaian suatu masalah atau pelaksanaan suatu pekerjaan yang terarah pada pencapaian tujuan tertentu. Perencanaan proses pembelajaran meliputi Silabus dan Rencana Pelaksanaan Pembelajaran (RPP) yang memuat identitas mata pelajaran, Standar Kompetensi (SK), Kompetensi Dasar (KD), indicator pencapaian kompetensi, tujuan pembelajaran, materi ajar, alokasi waktu, metode pembelajaran, kegiatan pembelajaran, penilaian hasil belajar, dan sumber belajar.

Dalam Permendikbud No. 22 Tahun 2016 tentang Standar Proses Pendidikan Dasar dan Menengah mengatakan Pelaksanaan pembelajaran merupakan implementasi dari RPP. Pelaksanaan pembelajaran meliputi kegiatan pendahuluan, kegiatan inti dan kegiatan penutup.

Menurut Rusman (2013: 13) penilaian dilakukan oleh guru terhadap hasil pembelajaran untuk mengukur tingkat pencapaian kompetensi peserta didik, serta digunakan sebagai bahan penyusunan laporan kemajuan hasil belajar, dan memperbaiki proses pembelajaran. Penilaian dilakukan secara konsisten, sistematis, dan terprogram dengan menggunakan tes dan nontes dalam bentuk tertulis atau lisan, pengamatan kinerja, pengukuran sikap, penilaian 
hasil karya berupa tugas, proyek dan/atau produk, portofolio, serta penilaian diri. Penilaian hasil pembelajaran menggunakan Standar Penilaian Pendidikan dan Panduan Penilaian Kelompok Mata Pelajaran.

Instalasi penerangan adalah suatu rangkaian beberapa komponen listrik dari sumber ke beban yang saling berhubungan satu sama lainnya secara listrik, yang terletak pada suatu tempat atau ruangan tertentu. Instalasi ini berupa titik cahaya sehingga terbentuklah suatu sistem yang mempunyai fungsi. Adapun fungsi dari sistem ini adalah untuk penerangan. Suatu instalasi penerangan dapat berfungsi dengan baik dan aman haruslah memenuhi syarat pemilihan pengaman dan penghantar. Menurut Trevor Linsley (2004: 169) adapun peristilahan-peristilahan umum dalam penerangan adalah sebagai berikut, 1) intensitas luminasi (I); 2) fluks luminasi (F); 3) iluminasi (E); 4) luminasi (L).

\section{Metode}

Pendekatan yang digunakan dalam penelitian ini adalah pendekatan kualitatif dimana adapun alasan pendekatan kualitatif digunakan seperti yang diungkapkan oleh Direktorat Tenaga Kependidikan (dalam Imam Gunawan, 2015: 105) yaitu (1) dalam penelitian ini hanya mendeskripsikan suatu proses kegiatan berdasarkan apa yang terjadi di lapangan, sebagai bahan kajian untuk menemukan kekurangan dan kelemahan sehingga ditentukan upaya penyempurnaannya; (2) menganalisis dan menafsirkan suatu fakta, gejala, dan peristiwa yang terjadi di lapangan sebagaimana adanya dalam konteks ruang dan waktu, serta situasi lingkungan suatu bidang kajian secara alami.

Jenis penelitian yang digunakan dalam penelitian ini yaitu deskriptif dimana dalam penelitian ini berusaha mendeskripsikan suatu gejala, peristiwa yang terjadi di lapangan. Peristiwa yang dimaksud yaitu berkenaan dengan proses pembelajaran pada mata pelajaran Instalasi Penerangan Listrik (IPL) dilihat dari segi perencanaan, pelaksanaan, dan penilaian yang dapat diteliti secara kualitatif.

SMK Negeri 3 Singaraja dipilih oleh peneliti sebagai tempat penelitian dikarenakan berdasarkan dengan pengamatan yang peneliti lakukan dimana peneliti menemukan masalah terkait dengan topik penelitian, adapun masalah yang ditemui sehingga diangkat menjadi topik skripsi yaitu kesenjangan atapun kurang sesuai antara perencanaan dengan pelaksanaan pembelajaran yang dilakukan di kelas sehingga pembelajaran menjadi kurang efektif.

Pemilihan sumber data dilakukan secara purposive sampling, yaitu pengambilan sumber data yang dipilih dengan berbagai atau atas pertimbangan-pertimbangan dan tujuan tertentu. Pertimbangan yang dimaksud yaitu orang yang dianggap paling tahu tentang apa yang kita harapkan atau orang yang paling berkompeten dan memiliki pengalaman yang cukup dalam bidang tertentu. Sumber data dalam penelitian ini adalah informan atau narasumber yang mengajar mata pelajaran Instalasi Penerangan Listrik (IPL) dan siswa kelas XI TIPTL sesuai pertimbangan dan tujuan dari penelitian ini. Data penelitian yang didapatkan data mentah dari hasil instrumen penelitian yang digunakan peneliti. Data yang didapat dari hasil penelitian ini yaitu dokumen-dokumen berupa perangkat mengajar guru seperti Rencana Pelaksanaan Pembelajaran (RPP), jobsheet, dan format penilaian, sedangkan data yang didapatkan dari siswa yaitu berupa hasil transkip wawancara siswa didalam mengikuti pelaksanaan pembelajaran pada mata pelajaran Instalasi Penerangan Listrik (IPL). Adapun teknik pengumpulan data yang digunakan dalam penelitian ini adalah sebagai berikut; 1) pengamatan atau observasi; 2) wawancara; 3 ) dokumentasi atau studi dokumen.

Penelitian kualitatif sebagai human instrument, berfungsi menetapkan fokus penelitian, memilih informan sebagai sumber data, melakukan pengumpulan data, menilai kualitas data, analisis data, menafsirkan data dan membuat kesimpulan atas temuannya. Pedoman observasi digunakan sebagai panduan dalam melakukan observasi untuk memperoleh data tentang proses pembelajaran Instalasi Penerangan Listrik (IPL) yang dilakukan oleh guru, meliputi kegiatan perencanaan, pelaksanaan, dan evaluasi pembelajaran. Pedoman wawancara digunakan untuk menggali informasi lebih mendalam mengenai proses pembelajaran Instalasi Penerangan Listrik (IPL). 
Analisis data dalam penelitian kualitatif dilakukan sejak sebelum memasuki lapangan, selama lapangan, dan setelah selesai di lapangan. Dalam hal ini Nasution (dalam Sugiyono: 336) menyatakan "Analisis telah mulai sejak merumuskan dan menjelaskan masalah, sebelum terjun ke lapangan, dan berlangsung terus sampai penulisan hasil penelitian". Namun dalam penelitian kualitatif, analisis data lebih difokuskan selama proses di lapangan bersamaan dengan bersamaan dengan pengumpulan data.

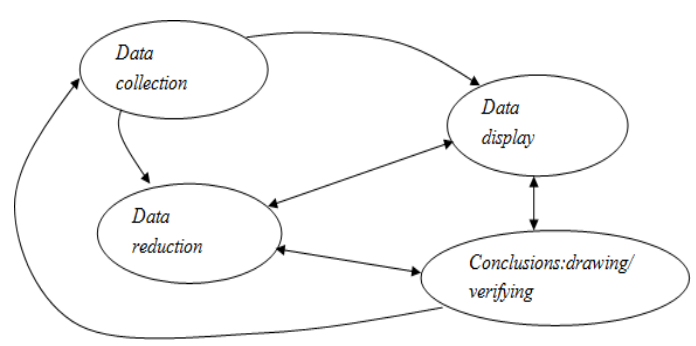

Gambar 1. Komponen dalam analisis data (interactive model)

Data reduction (reduksi data), Data yang diperoleh dari lapangan jumlahnya cukup banyak, untuk itu perlu dicatat secara teliti dan rinci. Seperti telah dikemukakan, makin lama peneliti ke lapangan, maka jumlah data akan makin banyak, kompleks dan rumit. Untuk itu perlu segera dilakukan analisis data melalui reduksi data. Mereduksi data berarti merangkum, memilih hal-hal yang pokok, memfokuskan pada hal-hal yang penting, dicari tema dan polanya dan membuang yang tidak penting. Dengan demikian data yang telah direduksi akan memberikan gambaran yang lebih jelas, dan mempermudah peneliti untuk melakukan pengumpulan data selanjutnya, dan mencarinya bila diperlukan. Reduksi data merupakan proses berfikir sensitif yang memerlukan kecerdasan dan keluasan dan kedalaman wawasan yang tinggi. Bagi peneliti yang masih baru, dalam melakukan reduksi data dapat mendiskusikan pada teman atau oranglain yang dipangdang ahli. Melalui diskusi itu, maka wawancara peneliti akan berkembang, sehingga dapat mereduksi data yang memiliki temuan dan pengembangan teori yang signifikan (Sugiyono, 2015: 338-339).

Data display (penyajikan data), Setelah data direduksi, maka langkah selanjutnya adalah mendisplaykan data. Dalam penelitian kualitatif, penyajian data bisa dilakukan dalam bentuk uraian singkat, bagan, hubungan antar kategori, flowchart dan sejenisnya. Dalam hal ini in Miles dan Huberman (dalam Sugiyono, 2015: 341) menyatakan yang paling sering digunakan untuk menyajikan data dalam penelitian kualitatif dengan teks yang bersifat naratif.

Conclusion drawing/verification, Langkah ke tiga dalam analisis kualitatif adalah penarikan kesimpulan data dan verifikasi. Kesimpulan awal yang dikemukakan masih bersifat sementara, dan akan berubah bila tidak ditemukan bukti-bukti yang kuat yang mendukung pada tahap pengumpulan data berikutnya. Dengan demikian kesimpulan dalam penelitian kualitatif mungkin dapat menjawab rumusan masalah yang dirumuskan sejak awal, tetapi mungkin juga tidak, karena seperti telah dikemukakan bahwa masalah dan rumusan masalah dalam penelitian kualitatif masih bersifat sementara dan akan berkembang setelah peneliti berada di lapangan. Kesimpulan dalam penelitian kulitatif yang diharapkan adalah merupakan temuan baru yang sebelumnya belum pernah ada. Temuan dapat berupa deskripsi atau gambaran suatu obyek yang sebelumnya masih remang- remang atau gelap sehingga setelah diteliti menjadi jelas, dapat berupa hubungan kausal atau interaktif, hipotesis atau teori (Sugiyono, 2015: 345).

Dalam penelitian kualitatif ini uji keabsahan data sering ditekankan pada uji validitas dan reliabilitas. temuan atau data dapat dinyatakan valid apabila tidak ada perbedaan antara yang dilaporkan peneliti dengan apa yang sesungguhnya terjadi pada obyek yang diteliti. Sedangkan dalam uji reliabilitas data dikatakan reliabel apabila dua atau lebih peneliti sama dalam kurun waktu berbeda menghasilkan data yang sama, atau sekelompok data bila dipecah menjadi dua menunjukkan data yang tidak berbeda. Data penelitian dalam kualitatif akan lebih kredibel atau dapat dipercaya dengan didukung oleh adanya studi dokumen atau 
dokumentasi yang berupa foto-foto selama kegiatan di lapangan, kajian perangkat pembelajaran guru.

\section{Hasil dan Pembahasan}

Berdasarkan analisis data dan kajian perangkat pembelajaran berupa RPP Instalasi Penerangan Listrik yang disusun dapat dipaparkan secara umum dimana susunan RPP guru telah memuat komponen-komponen RPP meliputi: 1) identitas sekolah yaitu nama satuan pendidikan; 2) identitas mata pelajaran; 3) kelas/semester; 4) materi pokok; 5) alokasi waktu; 6) tujuan pembelajaran; 7) kompetensi inti (KI) yang sesuai terhadap silabus bidang Instalasi Penerangan Listrik; 8) kompetensi dasar (KD) dan indikator dari $\mathrm{KI}-1$ (aspek spiritual), $\mathrm{KI}-2$ (aspek sosial), KI-3 (aspek pengetahuan), dan KI-4 (aspek keterampilan); 8) materi pembelajaran; 9) pendekatan dan model pembelajaran; 10) media, alat dan sumber belajar; 11) langkah-langkah pembelajaran yang terdiri dari kegiatan pendahuluan, kegiatan inti, dan penutup; 12) penilaian yang terdiri dari teknik, instrumen, dan rubrik penilaian. Secara garis besar RPP yang disusun oleh guru A dan B sudah sesuai dengan pendapat Kunandar (2015: 5) yang dimana komponen RPP terdiri atas: 1) identitas sekolah;2)

identitas mata pelajaran; 3) kelas/semester; 4) materi pokok; 5) alokasi waktu; 6) tujuan pembelajaran; 7) kompetensi dasar dan indicator pencapaian kompetensi; 8) materi pembelajaran; 9) metode pembelajaran; 10) media pembelajaran; 11) sumber belajar; 12) langkah-langkah pembelajaran; 13) penilaian hasil pembelajaran. Berdasarkan analisis data, dimana RPP yang disusun guru masih banyak terdapat kekurangan diantaranya pada RPP yang disusun oleh guru A belum terdapat materi pokok sedangkan RPP yang disusun oleh guru $B$ sudah tercantum materi pokok hanya saja materi pokok yang dicantumkan tidak sesuai dengan materi pokok yang ada disilabus.

Adapun komponen lain juga didapati perihal menyusun materi pembelajaran yang dimana dalam hal menyusun materi guru A belum memuat fakta, konsep, prinsip, dan prosedur sesuai dengan anjuran dari Permendikbud No. 22 Tahun 2016 sedangkan RPP yang disusun oleh guru B sudah memuat fakta, konsep, prinsip, dan prosedur. Berdasarkan hasil analisis data yang dilakukan terungkap bahwa masih banyak kekurangan dalam hal perencanaan pembelajaran khususnya RPP. Dengan kata lain, RPP yang disusun oleh masing-masing guru terkait belum sepenuhnya sesuai.

Melaksanakan program pada dasarnya mengimplementasikan program yang telah disusun dalam proses belajar mengajar di kelas. Hal ini berarti keberhasilan pelaksanaan pembelajaran sangat tergantung dari kualitas perencanaan pembelajaran yang telah disusun, terutama silabus dan RPP. Dengan perencanaan pembelajaran yang baik, akan menghasilkan pelaksanaan yang baik dan begitu juga sebaliknya. Dalam hal ini pelaksanaan pembelajaran harus mengacu pada RPP yang telah dibuat oleh guru. Secara umum dalam Permendikbud No. 22 Tahun 2016 tentang Standar Proses Pendidikan Dasar dan Pendidikan Menengah dibagi menjadi tiga kegiatan, yakni pendahuluan, inti, dan penutup. Berdasarkan hasil kajian pada RPP yang disusun oleh guru A dan B dalam merancang langkah-langkah pembelajaran membaginya menjadi 3 tahapan diantaranya pendahuluan, inti, dan penutup hal ini sudah sesuai dengan Permendikbud No. 22 Tahun 2016. Pembelajaran Instalasi Penerangan Listrik berdurasi 8 jam pelajaran disetiap pertemuannya atau setara dengan 360 menit. Berdasarkan kajian data hasil observasi dan wawancara siswa, kegiatan pendahuluan yang dilakukan oleh guru kurang sesuai dengan Permendikbud No. 22 Tahun 2016 dimana pada kegiatan pendahuluan guru hanya melakukan pengucapan salam, berdoa, lalu melanjutkan materi ataupun langsung memaparkan materi.

Menurut Permendikbud No. 22 Tahun 2016 dalam kegiatan pendahuluan, guru wajib: a) menyiapkan peserta didik secara psikis dan fisik untuk mengikuti proses pembelajaran; b) memberi motivasi belajar peserta didik secara kontekstual sesuai manfaat dan aplikasi materi ajar dalam kehidupan sehari-hari, dengan memberikan contoh dan perbandingan lokal, nasional dan internasional, serta disesuaikan dengan karakteristik dan jenjang peserta didik; c) mengajukan pertanyaan-pertanyaan yang mengaitkan pengetahuan sebelumnya dengan materi yang akan dipelajari; d) menjelaskan tujuan pembelajaran atau kompetensi dasar yang 
akan dicapai; e) menyampaikan cakupan materi dan penjelasan uraian kegiatan sesuai silabus.

Menurut Permendikbud Nomor 22 tahun 2016 menyatakan bahwa kegiatan inti menggunakan model pembelajaran, metode pembelajaran, media pembelajaran, dan sumber belajar yang disesuaikan dengan karakteristik peserta didik dan mata pelajaran. Guru A dan $B$ dalam melakukan proses pembelajaran menggunakan model pembelajaran berbasis masalah. Menurut Margetson (dalam Rusman, 2013: 230) mengemukakan bahwa kurikulum Problem Based Learning membantu untuk meningkatkan perkembangan keterampilan belajar sepanjang hayat dalam pola pikir yang terbuka, reflektif, kritis, dan belajar aktif. Kurikulum Problem Based Learning memfasilitasi keberhasilan memecahkan masalah, komunikasi, kerja kelompok dan keterampilan interpersonal dengan lebih baik dibanding pendekatan yang lain.

Berdasarkan hasil observasi, kegiatan penutup dilakukan oleh guru A dan B kurang lengkap sesuai dengan yang termuat dalam Permendikbud No. 22 Tahun 2016, dalam kegiatan penutup guru lebih cenderung: 1) melakukan kegiatan tindak lanjut dalam bentuk pemberian tugas, baik tugas individual maupun kelompok; 2) menginformasikan rencana kegiatan pembelajaran untuk pertemuan berikutnya. Menurut Permendikbud No. 22 Tahun 2016 dalam kegiatan penutup guru bersama peserta didik baik secara individual maupun kelompok melakukan refleksi untuk mengevaluasi: a) seluruh rangkaian aktivitas pembelajaran dan hasil-hasil yang diperoleh untuk selanjutnya secara bersama menemukan manfaat langsung dari hasil pembelajaran yang telah berlangsung; b) memberikan umpan balik terhadap proses dan hasil pembelajaran; c) melakukan kegiatan tindak lanjut dalam bentuk pemberian tugas, baik tugas individual maupun kelompok; d) menginformasikan rencana kegiatan pembelajaran untuk pertemuan berikutnya.

Menurut Kunandar (2015: 11) penilaian hasil belajar secara esensial bertujuan untuk mengukur keberhasilan pembelajaran yang dilakukan oleh guru dan sekaligus mengukur keberhasilan peserta didik dalam penguasaan kompetensi yang telah ditentukan. Dengan demikian, penilaian hasil belajar itu sesuatu yang sangat penting. Dengan penilaian guru bisa melakukan refleksi dan evaluasi terhadap kualitas pembelajaran yang telah dilakukan. Apakah metode, strategi, media, model pembelajaran dan hal lain yang dilakukan dalam proses belajar mengajar itu tepat dan efektif atau sebaliknya bisa dilihat dari hasil belajar yang diperoleh peserta didik.

Penilaian (assessment) adalah proses pengumpulan berbagai data yang bisa memberikan gambaram perkembangan belajar siswa. Gambaran perkembangan belajar peserta didik perlu diketahui oleh guru agar bisa memastikan bahwa peserta didik mengalami proses pembelajaran yang benar. Penilaian proses pembelajaran menggunakan pendekatan penilaian otentik yang menilai kesiapan peserta didik, proses, dan hasil belajar secara utuh. Berdasarkan analisis kajian perangkat pembelajaran RPP masing-masing guru secara garis besar telah memuat penilaian sikap, pengetahuan, dan keterampilan dan ini sudah sesuai dengan Permendikbud No. 23 Tahun 2016. Penilaian sikap sebagaimana dimaksud merupakan kegiatan yang dilakukan pendidik untuk memperoleh informasi deskriptif mengenai perilaku peserta didik. Penilaian pengetahuan sebagaimana dimaksud merupakan kegiatan yang dilakukan untuk mengukur penguasaan pengetahuan peserta didik. Penilaian keterampilan sebagaimana dimaksud merupakan kegiatan yang dilakukan untuk mengukur kemampuan peserta didik menerapkan pengetahuan dalam melakukan tugas tertentu.

Guru tidak mencantumkan program perbaikan (remedial) pembelajaran, pengayaan (enrichment) dalam hal memperbaiki proses pembelajaran pada RPP seperti yang dianjurkan pada Permendikbud No. 22 Tahun 2016. Berdasarkan kajian perangkat pembelajaran dimana pada penilaian sikap guru tidak mencantumkan penilaian diri dan penilaian antar teman guru hanya mencantumkan berdasarkan pengamatan/observasi, pada penilaian pengetahuan tidak tercantum tes lisan dan penugasan, hal ini kurang sesuai dengan Kemdikbud 2016 tentang Panduan Penilaian Oleh Pendidik dan Satuan Pendidikan untuk Sekolah Menengah Atas. Yang dimana menurut Kemdikbud 2016 termuat penilaian sikap terdiri dari penilaian observasi, penilaian diri dan penilaian antarteman, penilaian pengetahuan terdiri dari tes 
tertulis, tes lisan, dan penugasan, penilaian pengetahuan terdiri dari penilaian unjuk kerja, proyek, portofolio, produk. Pada penilaian keterampilan guru hanya menggunakan penilaian unjuk kerja dan portofolio.

Berdasarkan hasil wawancara yang dilakukan dengan guru A dan B dimana didapati faktor-faktor yang mempengaruhi kurang sesuainya antara perencanaan dengan pelaksanaan di dalam pembelajaran instalasi penerangan listrik diantaranya waktu, ketidaksamaan kemampuan yang dimiliki oleh masing-masing siswa, media yang digunakan, sarana dan prasarana, kondisi kelas itu sendiri. Berdasarkan hasil observasi yang telah dilakukan bahwa salah satu faktor muncul yaitu dilihat dari kondisi kelas, untuk mengkondisikan kelas pada siswa SMK memang terbilang agak sulit terlebih guru itu sendiri harus mengetahui karakteristik masing-masing dari siswa itu sendiri. Seperti misalnya pada observasi kedua yang dimana pada pertemuan sebelumnya guru sudah mengingatkan seluruh siswa untuk membawa perlengkapan menggambar dan disisi lain pada pertemuan yang dijanjikan terlihat masih banyak siswa yang tidak membawa peralatan gambar akibatnya kegiatan merencanakan jadi terhambat.

Hal ini sesuai dengan Wina Sanjaya (2010: 52) yang menyatakan bahwa terdapat beberapa faktor yang dapat mempengaruhi kegiatan proses sistem pembelajaran, selain di antaranya ada faktor guru dan faktor lingkungan juga ada faktor siswa, sarana, alat dan media yang tersedia. Pada siswa faktor-faktor yang dapat mempengaruhi proses pembelajaran dilihat dari aspek siswa meliputi aspek latar belakang siswa menurut Dunkin disebut (pupil formative experiences) serta faktor sifat yang dimiliki siswa (pupil properties). Dilihat dari sifat yang dimiliki siswa meliputi kemampuan dasar, pengetahuan, dan sikap. Tidak dapat disangkal bahwa setiap siswa memiliki kemampuan yang berbeda yang dapat dikelompokkan pada siswa berkemampuan tinggi, sedang dan rendah.

Siswa yang termasuk berkemampuan tinggi biasanya ditunjukkan oleh motivasi yang tinggi dalam belajar, perhatian, dan keseriusan dalam mengikuti pelajaran. Sebaliknya, siswa yang tergolong pada kemampuan rendah ditandai dengan kurangnya motivasi belajar, tidak adanya keseriusan dalam mengikuti pelajaran, termasuk menyelesaikan tugas. Perbedaanperbedaan semacam itu menuntut perlakuan yang berbeda pula baik dalam penempatan atau pengelompokkan siswa maupun dalam perlakuan guru dalam menyesuaikan gaya belajar. Demikian juga halnya dengan tingkat pengetahuan siswa.

Siswa yang memiliki pengetahuan yang memadai tentang penggunaan bahasa standar, misalnya akan mempengaruhi prose pembelajaran mereka dibandingkan dengan siswa yang tidak memiliki tentang hal itu. Sikap dan penampilan siswa di dalam kelas juga merupakan aspek lain yang bisa mempengaruhi proses pembelajaran.

Ada kalanya ditemukan siswa yang sangat aktif (hyperkinetic) dan ada pula siswa yang pendiam, tidak sedikit juga ditemukan siswa yang memiliki motivasi yang rendah dalam belajar. Semua itu akan mempengaruhi proses pembelajaran di dalam kelas. Sebab, bagaimanapun faktor siswa dan guru merupakan faktor yang sangat menentukan dalam interaksi pembelajaran.

Sarana adalah segala sesuatu yang mendukung secara langsung terhadap kelancaran proses pembelajaran, misalnya media pembelajaran, alat-alat pelajaran, perlengkapan sekolah. Kelengkapan sarana dan prasarana dapat menumbuhkan gairah dan motivasi guru mengajar. Mengajar dapat dilihat dari dua dimensi, yaitu sebagai proses penyampaian materi pelajaran dan sebagai proses pengaturan lingkungan yang dapar merangsang siswa untuk belajar. Jika mengajar dipandang sebagai proses penyampaian materi, maka dibutuhkan sarana pembelajaran berupa alat dan bahan yang dapat menyalurkan pesan secara efektif dan efisien; sedangkan manakala mengajar dipandang sebagai proses mengatur lingkungan agar siswa dapat belajar, maka dibutuhkan sarana yang berkaitan dengan berbagai sumber belajar yang dapat mendorong siswa untuk belajar.

Dengan demikian, ketersediaan sarana yang lengkap memungkinkan guru memiliki berbagai pilihan yang dapat digunakan untuk melaksanakan fungsi mengajarnya; dengan demikian, ketersediaan ini dapat meningkatkan gairah mengajar mereka. Kelengkapan sarana dan prasarana dapat memberikan berbagai pilihan pada siswa untuk belajar. Setiap siswa 
pada dasarnya memiliki gaya belajar yang berbeda. Siswa yang bertipe auditif akan lebih mudah belajar melalui pendengaran; sedangkan tipe siswa yang visual akan lebih mudah belajar melalui penglihatan. Kelengkapan sarana dan prasarana akan memudahkan siswa menentukan pilihan dalam belajar.

\section{Kesimpulan dan Saran}

Berdasarkan hasil penelitian dan pembahasan, maka dapat disimpulkan bahwa secara garis besar, susunan RPP guru telah memuat komponen-komponen RPP yang berdasarkan Permendikbud No. 22 Tahun 2016. Namun, ada beberapa komponen RPP yang disusun masih memiliki kekurangan, diantaranya: 1) tidak mencantumkan materi pokok; 2) tidak mencantumkan pedoman penilaian sikap yang terdiri dari penilaian diri untuk peserta didik dan penilaian antarteman untuk peserta didik; 3) tidak dilengkapi dengan instrumen pengayaan dan remedial.

Pelaksanaan pembelajaran Instalasi Penerangan Listrik (IPL) pada siswa kelas XI SMK Negeri 3 Singaraja terdiri dari tiga tahapan, yaitu pendahuluan, inti dan penutup. Pada kegiatan pendahuluan guru kurang mengikuti ketentuan dari Kurikulum 2013 dimana pada kegiatan pendahuluan guru melakukan pengucapan salam, doa, dan melanjutkan materi. Pada kegiatan inti, dalam pembelajaran instalasi penerangan listrik guru menggunakan model pembelajaran yaitu Problem Based Learning.

Pada kegiatan penutup yang dilakukan guru kurang lengkap sesuai instruksi Kurikulum 2013 yang dimana guru hanya: 1) melakukan kegiatan tindak lanjut dalam bentuk pemberian tugas, baik tugas individual maupun kelompok; 2) menginformasikan rencana kegiatan pembelajaran untuk pertemuan berikutnya. Evaluasi pembelajaran Instalasi Penerangan Listrik kelas XI SMK Negeri 3 Singaraja terdiri dari tiga aspek, yaitu aspek sikap, aspek pengetahuan, dan aspek keterampilan. Item-item pada setiap aspek tidak semuanya terlaksana, seperti penilaian penilaian diri untuk peserta didik, penilaian antar teman untuk peserta didik, guru hanya membawa lembar penilaian portofolio dalam mengajar di kelas. Faktor-faktor yang mempengaruhi antara perencanaan pembelajaran dengan pelaksanaan diantaranya meliputi waktu, kondisi kelas dan siswa, ketidaksamaan kemampuan siswa.

Adapun beberapa saran yang dapat disampaikan oleh peneliti terkait penelitian yang telah dilakukan yaitu, Dalam merencanakan pembelajaran guru diharapkan lebih cermat dan sistematis dalam menyusun RPP dan menyesuaikan dengan peraturan perundang- undangan Kurikulum 2013 yang berlaku agar tidak ada komponen RPP yang tidak tercantum. Guru diharapkan lebih ideal dalam melaksanakan pembelajaran yang terdiri dari tiga tahap, yaitu pendahuluan, inti dan penutup.

\section{Daftar Pustaka}

Kunandar. 2015. Penilaian Autentik (Penilaian Hasil Belajar Peserta Didik Berdasarkan Kurikulum 2013). Cetakan ke-4. Jakarta: Rajawali Pers.

Linsley, Trevor. 2004. Instalasi Listrik Tingkat Lanjut Edisi ke-3. Jakarta: Erlangga.

Majid, Abdul. 2009. Perencanaan Pembelajaran Mengembangkan Standar Kompetensi Guru. Bandung: PT. Remaja Rosdakarya.

Mulyasa, H. E. 2010. Implemenasi Kurikulum Tingkat Satuan Pendidikan Kemandirian Guru dan Kepala Sekolah. Jakarta: Bumi Aksara.

Peraturan Menteri Pendidikan dan Kebudayaan Republik Indonesia No. 22 Tahun 2016 tentang Standar Proses Pendidikan Dasar dan Menengah. (Diunduh tanggal 09 Agustus 2017). 
Rusman. 2013. Model-model Pembelajaran: Mengembangkan Profesionalisme Guru. Jakarta: Rajawali Pers.

Sanjaya, Wina. 2010. Strategi Pembelajaran Berorientasi Standar Proses Pendidikan. Edisi 1, Cetakan ke-7. Jakarta: Kencana.

Sugiyono. 2015. Metode Penelitian Pendidikan (Pendekatan Kuantitatif, Kualitatif, dan R\&D). Cetakan ke-21. Bandung: Alfabeta.

Sukardi. 2014. Evaluasi Program Pendidikan dan Kepelatihan. Jakarta: Bumi Aksara. Tayibnapis, Farida Yusuf. 2008. Evaluasi Program dan Instrumen Evaluasi. Jakarta: Rineka

Cipta.

Undang-Undang Republik Indonesia No.20 Tahun 2003 tentang Sistem Pendidikan Nasional, 2007. Jakarta: Sinar Grafika. 